NUREG/GR-1574

UCID-18671

\title{
Data Requirement Comparison Between the Fixed Site Upgrade Rule Guidance Compendium and the Structured Assessment Approach Licensee Submittal Document
}

A. A. Parziale, Lawrence Livermore National Laboratory

I. J. Sacks, Analytic Information Processing, Inc.

Prepared for

U.S. Nuclear Regulatory Commission

DO NOT MicinuriLM
COVER

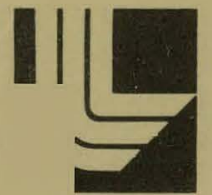

LAWRENCE LIVERMORE 


\section{DISCLAIMER}

This report was prepared as an account of work sponsored by an agency of the United States Government. Neither the United States Government nor any agency Thereof, nor any of their employees, makes any warranty, express or implied, or assumes any legal liability or responsibility for the accuracy, completeness, or usefulness of any information, apparatus, product, or process disclosed, or represents that its use would not infringe privately owned rights. Reference herein to any specific commercial product, process, or service by trade name, trademark, manufacturer, or otherwise does not necessarily constitute or imply its endorsement, recommendation, or favoring by the United States Government or any agency thereof. The views and opinions of authors expressed herein do not necessarily state or reflect those of the United States Government or any agency thereof. 


\section{DISCLAIMER}

Portions of this document may be illegible in electronic image products. Images are produced from the best available original document. 


\section{DISCLAIMER}

This document was prepared as an account of work sponsored by an agency of the United States Government. Neither the United States Government nor any agency thereof, nor any of their employees, makes any warranty, expressed or implied, or assumes any legal liability or responsibility for the accuracy, completeness, or usefulness of any information, apparatus, product, or process disclosed, or represents that its use would not infringe privately owned rights. Reference herein to any specific commercial product, process, or service by trade name, trademark, manufacturer, or otherwise, does not necessarily constitute or imply its endorsement, recommendation, or favoring by the United States Government or any agency thereof. The views and opinions of authors expressed herein do not necessarily state or reflect those of the United States Government or any agency thereof.

This work was supported by the Unites States Nuclear Regulatory Commission under a Memorandum of Understanding with the United States Department of Energy.

Available from

GPO Sales Program

Division of Technical Information and Document Control

U.S. Nuclear Regulatory Commission

Washington, D.C. 20555

and

National Technical Information Service

Springfield, Virginia 22161 


\section{DISCLAIMER}

This report was prepared as an account of work sponsored by an agency of the United States Government. Neither the United States Government nor any agency thereof, nor any of their employees, makes any warranty, express or implied, or assumes any legal liability or responsibility for the accuracy, completeness, or usefulness of any information, apparatus, product, or process disclosed, or represents that its use would not infringe privately owned rights. Refer-

- ence herein to any specific commercial product, process, or service by trade name, trademark, manufacturer, or otherwise does not necessarily constitute or imply its endorsement, recommendation, or favoring by the United States Government or any agency thereof. The views and opinions of authors expressed herein do not necessarily state or reflect those of the - - United States Government or any agency thereof.
NUREG/CR-1574

UCID-18671

RS

\section{Data Requirement Comparison Between the Fixed Site Upgrade Rule Guidance Compendium and the Structured Assessment Approach Licensee Submittal Document}

Manuscript Completed: December 1980

Date Published:

Prepared by

A. A. Parziale, Lawrence Livermore National Laboratory

I. J. Sacks, Analytic Information Processing, Inc.

Lawrence Livermore Laboratory

7000 East Avenue

Livermore, CA 94550

Prepared for

Office of Nuclear Regulatory Research

U.S. Nuclear Regulatory Commission

Washington, D.C. 20555

NRC FIN No. A-0115 
THIS PAGE

WAS INTENTIONALLY

LEFT BLANK 


\section{FOREWORD}

The work described in this report was conducted by the Nuclear Systems Safety/Safeguards Program at Lawrence Livermore National Laboratory for the U.S. Nuclear Regulatory Commission Office of Nuclear Regulatory Research under FIN number A0115. This ciocument deals with the Structurea Assessment Approach, a technique for automated vulnerability assessment of fixed-site nuclear fuel cycle facilities developed for the NRC, which is described fully in four volumes:

A. A. Parziale and I. J. Sacks. Structured Assessment Approach. Version 1. Analys is Package (Executive Summary), Vo 1. 1. Lawrence Livermore National Laboratory, Livermore, CA. NUREG/CR-1233, Vo1. I, UCRL-52735, Voi. 1.

A. A. Parziale and I. J. Sacks. Structured Assessment Approacn. Version 1. Licensee Submittal Document Content and Format for Material Control and Accounting Assessment, Vo 1. 2. Lawrence Livermore National Laboratory, Livermore, CA. NUREG/CR-1233, Vo1. 2, UCRL. 52735, Voil. 2.

A. A. Parziale and I. J. Sacks. Structured Assessment Approach. Version 1. Applied Demonstration of Output Results, Vol. 3 . Lawrence Livermore National Laboratory, Livermore; CA. NUREG/CR-1233, Vo 1. 3, UCRL-52735, Vo 1. 3.

A. A. Parziale and I. J. Sacks. Structured Assessment Approach. Version 1. Computational Analysis rackage, Vo 1. 4. Lawrence Livermore National Laboratory, Livermore, CA. NUREG/CR-1233, Vo1. 4, UCID-18146.

The comparison reported upon nerein was motivated by requests from Dr. R. Shepard (NRC/RES) and Mr. J. Part low (NRC/NMSS) to compare the data requirements of the Licensee Submittai Document and the Fixed Site Physicai Protection Upgrade Rule Guidance Compendium.

$$
i i j / r
$$


Abstract ................................ vi

Executive Summary ... . . . . . . . . . . . . . . . . ix

Introduction . . . . . . . . . . . . . . . . ....... 1

Objective of Study ..................... 1

Scope of Study ........................ 1

Summary Tabulation of Comparison Results . . . . . . . . . . . . . 2

Major Findings and Impact on Assessment . . . . . . . . . . . . 6

Facility Layout and Location . . . . . . . . . . . . . . 7

SNM Piping System Information . . . . . . . . . . . . . . 7

Procedure Information . . . . . . . . . . . . . . . 8

Control and Tamper Monitor Information . . . . . . . . . . 8

Utility System Information . . . . . . . . . . . . . . 9

Signal Transmission System Information .............. 9

Facility Personnel Access and Control . . . . . . . . . . . 10

Facility Operational Mode Information . . . . . . . . . . . 10

Component Probabilistic Information . . . . . . . . . . . 11

Safeguards Interconnectivity Information ............. 11

SFC Guide Format and Organization . . . . . . . . . . . . 1 li

Summary and General Recommendations . . . . . . . . . . . . . . 14

Acknowledgments . . . . . . . . . . . . . . . . . 15

References ....................... . . . 16

Appendix A . . . . . . . . . . . . . . . . . . 17 
We compared the Structured Assessment Approach's (SAA) Licensee Subrittal Document (LSD) with the Fixed Site Physical Protection Upgrade Rule Guidarice Compendium St andard Format and Content (SFC) Guide using correlation matrices to see how well the data requirements of the SFC Guide coincided with those of a specific automated vulnerability assessment technique for fixed-site nuclear fuel cycle facilities, namely, SAA. We found that a limited SAA assessment is possible using the SFC Guide, but significant and critical sateguaras vulnerabilities might be missed. Also, it was found that in some cases the organization and format of the SFC Guide input data and information made the preparation of data for the SAA somewhat awkward. 
In this report we summarize the major findings and conclusions of a comparison between the data requirements of the Structured Assessment Approach (SAA) Licensee Submittal Document $(\text { LSD })^{l}$ and those of the Nuclear Regulatory Commission Fixed Site Physical Protection Upgrade Rule Guidance Compendium, Standard Format and Content (SFC) Guide. 2

The objective of this effort is twofold. The first is to determine the information on the facility and the safeguards system that the LSD elicits but the SFC Guide does not. The second is to estimate the impact on and the limitations to an SAA assessment caused by the limited information elicited by the SFC Guide. When differences in data format and organization between the LSD and SFC documents had a significant impact on performing an assessment, we included them in this report as well.

The results, conclusions, and recommendations presented in this report are based upon a comparison between the SAA (Version 1, October 1979 status) and the December 21, 1978, NRC draft of the "Fixed Site Upgrade Rule Guidance Compendium" and recent revisions to that draft report entitled Attachment $A$, "Sample Portion of Security Plan" dated September 19, 1979, and Appendix I, "Component List Information Request Sheets" dated October 5, 1979. We concentrated on the review of Attachment $A$ and Appendix I because they are more current and regard information description in finer detail.

The results of the study are captured in the following summarizing statements. The most significant deficiencies in the SFC Guide information requirements when viewed in the context of the SAA LSD requirements include:

- Special Nuclear Material (SNM) piping system information is absent.

- Safeguards system interconnectivity information is incomplete.

- Signal transmission and utility system information is incomplete.

- Probabilistic information is incomplete.

- Licensee interpretation of SFC requests may be sufficiently uncertain to preclude data conpleteness. 
The impact of these SFC Guide information deficiencies upon performing an SAA assessment include:

- A fairly thorough Level 1 (diversion path coverage) analys is is possible.

- At least partial Level 2 (adequacy), Level 3 (sensitivity), and Level 4 (tampering) analyses are possible.

- Reorganizing and reformatting the SFC Guide input data and information may often simplify an automated assessment.

- Significant and critical safeguards vulnerabilities could be missed due to lack of input data as obtained from the SFC Guide.

In light of the independent, parallel development of the SFC Guide and the SAA LSD, each addresses surprisingly similar information. Also, new NRC initiatives regarding information requests, especially recent revisions to the SFC Guide document, appear to be such as to more readily accommodate automated vulnerability assessments. 
The purpose of this report is to summarize the comparison between the SAA LSD $^{1}$ and the NRC Fixed Site Physical Protection Upgrade Rule Guidance Compendium, SFC. ${ }^{2}$

\section{OBJECTIVE OF STUDY}

The objective of this effort is to determine the information on the facility and safeguards system that the LSD elicits but the SFC Guide does not, and to estimate the impact on and limitations to an SAA assessment caused by the limited information elicited by the SFC guide. When differences in data format and organization between the LSD and SFC documents have a significant impact on performing an assessment, we have included them in this report as well.

SCOPE OF STUDY

The results, conclusions, and recommendations presented in this report are based upon a comparison between the SAA (Version 1, October 197.9 status) and the December 21, 1978, NRC draft of the "Fixed Site Upgrade Rule Guidance Compendium" and recently received revisions to that draft report entitled Attachment A, "Sample Portion of Security Plan," dated September 19, 1979, and Appendix I, "Componenent List Information Request Sheets," dated October 5, 1979. We concentrated on the review of Attachment $A$ and Appendix I because they are current and regard information description in finer detail.

This report is organized into three sections as follows:

1. Summary tabulation of comparison results

2. Major finding and impact on assessment

3. Summary and general recommendations 
This section provides the results of comparing the information elicited by the LSD and SFC. It also provides estimates of the impact of using the limited information which the SFC elicits on performing an SAA assessment.

The LSD elicits information in certain categories, each of which, in general, pertains to distinguishable and identifiable safeguard items, components, or procedures. Table 1 identifies those coarse categories of information which are used by the LSD to perform each SAA level of analysis. The essential question each level of analysis addresses follows:

Level 1: Are all diversion paths covered?

Level 2: Are all diversion paths covered adequately?

Level 3: Is the adequacy of diversion path coverage sensitive to failures?

Level 4: Is the safeguards system vulnerable to tampering?

In addition, collusion analyses are performed at Levels 1, 3, and 4. Although not expressed in Table 1, the information gathered in Level 1 is a necessary requirement for performing Levels 2, 3, and 4 .

The last two categories in Table 1, Component probabilistic data and Safeguards interconnectivity information, pertain to two basic kinds of information about safeguards components in general. Component probabilistic data refers to probability of detection and component availability statistics, such as mean time to failure and repair, for relevant safeguards components. Safeguards interconnectivity information refers to logical and physical relationships and dependencies between or among safeguards components.

In comparing the information elicited by both documents, we found, for example, that the SFC Guide could elicit all the required information on facility layout and location, none of the required information on SNM piping information, and approximately three-quarters of the required information on material transfer procedures. We estimated the percentage of information in each LSD category that is elicited by the SFC Guide and have presented the 
Table 1: Categories of LSD Information Used at Each SAA Level of Analysis

SAA Levels

\begin{tabular}{|c|c|c|c|}
\hline $\begin{array}{c}\text { Level } 1 \\
\text { Coverage/Collusion }\end{array}$ & $\begin{array}{r}\text { Level } 2 \\
\text { Adequacy }\end{array}$ & $\begin{array}{c}\text { Level } 3 \\
\text { Sensitivity/Collusion }\end{array}$ & $\begin{array}{c}\text { Level } 4 \\
\text { Tampering/Collusion }\end{array}$ \\
\hline
\end{tabular}

\section{LSD Information Categories}

Facility Layout and Locations

Piping System Elements

Material Transfer Procedures

Control and Tamper Monitors

¿ Utility System Components

Signal Transmission System Components

Fac ${ }^{\circ}$ lity Personnel Access and Control

Accounting System Components

Facility Operational Modes

Component Probabitistic Data

S/G Interconnectivity Information
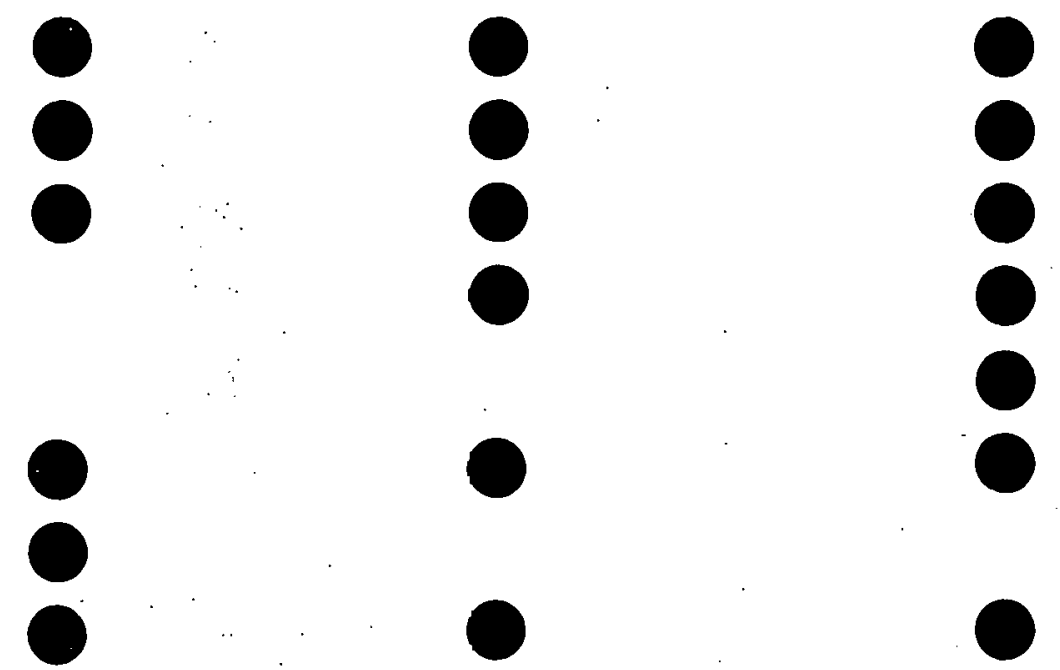
results in Table 2. The estimates are rough, but come from careful review of the SFC Guide. The actual information received will vary according to the lisencee's interpretation of the requests the SFC makes. The information missing in each category is discussed in detail in the following section.

Even though the SFC elicits too little information to support a full SAA assessment, it is capable of obtaining sufficient kinds and amounts of information to support at least a partial analysis at each SAA level.

Using information gathered by the SFC Guide, approximately $75 \%$ of Level 1 could be completed, and $50 \%$ of Levels 2, 3, and 4 (Table 2). At Level 1, the absence of SNM piping system information may cause potential theft targets to be overlooked. At Levels 2, 3, and 4 the lack of safeguards interconnectivity information, especially with regard to signal transmission and utility systems, is the most significant limiting factor. The limited data available may leave the collusion sets determined by the SAA incomplete. Individuals may be able to use their access and control to move material through piping to unprotected points, or defeat protection systems by access to signal transmission paths or utility components.

The specific impact of particular information category deficiencies on assessment output results is addressed in more detail in the next section. 
Table 2. Estimate of Portion of Information which may be Elicited by the SFC Guide and an Estimate of Assessment Output Impact.

\begin{tabular}{|c|c|c|c|c|}
\hline \multirow{2}{*}{$\begin{array}{l}\text { For SFC Guide } \\
\text { LSD INFORMATION CATEGORIES }\end{array}$} & \multicolumn{4}{|c|}{ SAA Levels } \\
\hline & Level 1 & Level 2 & Level 3 & Level 4 \\
\hline Facility Layout and Locations & 0 & NA & NA & 0 \\
\hline Piping System Elements & 0 & NA & NA & NA \\
\hline Material Transfer Procedures & 0 & NA & NA & NA \\
\hline Control and Tamper Monitors & 0 & 0 & 0 & 0 \\
\hline Utility System Components & NA & 0 & 0 & D \\
\hline Signal Transmission System Components & NA & 0 & 0 & D \\
\hline Facility Personnel Access and Control & 0 & NA & 0 & 0 \\
\hline Accounting System Components & NA & NA & NA & 0 \\
\hline Facility Operational Modes & 0 & 0 & 0 & 0 \\
\hline Component Probabilistic Data & NA & 0 & NA & NA \\
\hline S/G Interconnectivity Information & NA & D & D & $\mathbf{0}$ \\
\hline $\begin{array}{l}\text { Estimate of amount of output given partial } \\
\text { absence of input information }\end{array}$ & 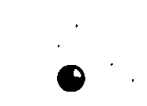 & 0 & 0 & 0 \\
\hline
\end{tabular}

Key: Information Available
$0 \%$
(1) $50 \%$
○ $25 \%$
$75 \%$
$100 \%$
NA Not Applicable 
This section presents major SFC. Guide information deficiencies and attempts to estimate the impact of these deficiencies on assessment output results. We had to approximate and extrapolate to assess impact, because of the uncertainty concerning how the nuclear facility licensee may interpret and respond to particular information requests forwarded in the SFC Guide. Uncertainty in licensee response is primarily due to occasional vagueness in SFC Guide elicitation questions. The format and organization of the SFC Guide should assure greater certainty of obtaining the desired information content about the facility and safeguards system. This issue is addressed in more detail in subsequent subsections.

The remainder of this section is organized into the following subsections:

- Facility Layout and Location Information

- SNM Piping System Information

- Procedures Information

- Control and Tamper Monitor Information

- Utility System Information

- Signal Transmission System Iriformation

- Facility Personnel Access and Control

- Facility Operational Mode Information

- Component Probabilistic Information

- Safeguards Interconnectivity Information

- SFC Guide Format/Organization Impact on Assessment

In each subsection, the differences in the amount, type, and importance of the information elicited by each of the documents is discussed. Having found these differences, we also discuss the deficiencies and problems encountered in attempting an SAA automated assessment using the SFC Guide rather than the LSD. 
FACILITY LAYOUT AND LOCATION - INFORMATION

Finding

The SFC guide will most likely elicit the necessary facility layout ano location information. However, the SFC Guide does not explicitly request the licensee to reference and uniquely label location, rooms, portals, ano barriers, or the safeguards components which will reside in particular locations in the facility.

$\underline{\operatorname{Impact}}$

The NRC analyst must reference and label locations, safeguaras components, etc., and verify with the facility licensee any of his assumptions. Since the licensee is obviously most knowledgeable about the particular facility under assessment, he is therefore better suited to perform the identification and labeling process than the NRC analyst.

SNM PIPING SYSTEM INFORMATION

Finding

The SFC Guide elicits virlually none of the SNM piping information addressed. in the SAA LSD. However, it identifies itemizea materiai and its location as potential SNM theft targets, as does the I.Sn.

Impact

The SAA diversion path analysis will nut identify tneft targets associated with piping systems, bccause the SFC Guide does not elicit the piping system information. The licensee aro analyst can diminish this inadequacy by identifying the potential Material Access Points (MAP) in the processirig system by direct visual inspection anc then treating the MAP as if they were itemized containers of SNM stored at the location of the MAP. 
PROCEDURE INFORMATION

Finding

Section 18 of the SFC Guide proviaes most of the information for describing procedures. However, in some cases the narrative descriptions are unclear, especially those dealing with protective measures ana tamper mechanisms that protect operational aspects associated with procedures.

$\underline{\text { Impact }}$

A fairly thorough assessment of procedures is possible. The assessment would be more thorough and more organized if it elicited information first at a coarse level and then at progressively finer levels of detail as the LSD does.

CONTROL AND TAMPER MONITOR INFORMATION

Finding

The SFC Guide addresses most of true structural ana physical data pertaining to safeguards monitors, but a few weak areas were found. Aspects of monitors which were captured adequately for tre most part include monitur field of view, required utilities for proper operation, physical iocation of the device, personnel control and access to the monitor, tamper protection, and device annunciation. Not addressea is the information on monitor signal transmission paths and the information on the effects that facility operational modes have on monitor on-off status. These deficiencies are discussed again in the following sections.

Impact

The information is sufficient to perform analyses. In a few cases, additional information may have to be obtainea from the licensee. 


\section{UTILITY SYSTEM INFORMATION}

\section{$\underline{\text { Finding }}$}

The SFC Guide elicits utility arıd power system information at a coarser level of detail than the LSD. The SFC Guide elicits information concerning secondary alarm station power supplies, controlled security lighting, emergency generator systems, night vision illumination ana uninterruptible power systems. But it does not explicitly eicit information concerning the distribution of utilities and power from primary anu back-up power sources to safeguards components which require the ulitities.

\section{Impact}

Not all potential vulnerabilities associated with components trat distribute utilities and power can be determined by the assessment, because these components are not uniqueily identified at the data input. Singie failures which defeat the safeguards system may be missed.

SIGNAL TRANSMISSION SYSTEM INFORMATION

\section{Finding}

The only reference to signal transmission path information in the SFC Guide is found within the information request sheets under the heading "Interfaces Bctween Aldril Station and Sensors....". In our estimate, signal transmission paths from monitors to specific annunciators, including the primary and secondary alarm stations, will not be properly identified.

\section{Impact}

The assessment cannut determine ail the potential vilnerabilities associated with. the transmission of detection signals. Single component failures in the signal transmission system that defeat the safeguaras system may be missed. 
FACILITY PERSONNEL ACCESS AND CONTROL

Finding

The SFC Guide requests personnel access and controi information for most of the safeguards system components the Guide adaresses. Informatiori seems to be missing on CCTV monitoring. Information concerning authorized control ano access to utility and signal transmission lines is incomplete, at least to the extent that not all of these components are explicitly adaressed in the SFC Guide.

$\underline{\text { Impact }}$

The assessment cannot determine all potential collusion vulnerabilities associated with insider tampering and misuse of safeguaras components, because complete access and control information is not specified. We still estimate, however, that the assessment can achieve many valuable collusion results.

FACILITY OPERATIONAL MODE INFORMATION

\section{Finding}

The SFC Guide does not explicitly request information about operational modes, of the facility with the exception of the emergency modes, sucn as evacuation. It does not request information about the normal operating modes of the facility or these modes' effect upor the safeguards system.

\section{Impact}

The assessment can determine the diversion path coverage, as well as the adequacy and sensitivity of that coverage, for only those facility operationai modes specified by the licensee. 
Finding

The SFC Guide requests most of the probabilistic and statistical information for monitors and other safeguards components, including probability of detection for monitors, mean time between failure, maintenance/inspection/supervision policy, ana tamper protection delay times. Information missing includes the probability of false alarms for monitors and the mean time to repair statistic for safeguards components in general.

Impact

A probability of detection adequacy analysis of diversion path cuverage appears to be possible, at least in rougn approximation, since the probabilistic information is requestea. The NRC anaiyst can fi i in the missing data subjectively. However, the lack of interconnectivity information, discussed subsequentiy, will cause an over-estimate of the performance of these systems.

SAFEGUARDS INTERCONNECTIVITY INFORMATION

Finding

The SFC Guide lacks safeguards interconnectivity information that. describes the relationships and dependencies between or among safeguards components, especially with respect to signal transmission lines and utility distribution systems. This is primarily due to the way in which the Guide elicits information. The Guide requests information about safeguards components, such as monitors, at a local level, but does not require the unique identification and labeling of the signal liries and utility components that are connected to each safeguards component. As à result, we cannot establish the correct interconnectivity of the safeguaris system as an integrated whole, especially with respect to signai transmission lines and 
utility distribution systems. :As an example, in responding to two different and separate information requests, the licensee may refer to an emergency. back-up power generator. Since the licensee is not requirea to uniquely identify each safeguarcis component, we are completely unable to determine if he is referring to two different power generators or if these generators are indeed one and the same.

$\underline{\text { Impact }}$

The assessment may overlook critical component failures ana vulnerabilities, because of the lack of interconnectivity information. The assessment may also overestimate the probability of detection adequácy measures in favor of the safeguards system, because the SFC Guide does not identify all the components which contribute to the unavailability of the safeguards system.

SFC GUIDE FORMAT AND ORGANIZATION

Finding 1

The SFC Guide does not have a standard format for information requests pertaining to the same kinds of safeguards components. The absence of a standard elicitation format is most noticeable for safeguarus monitors and detection devices, although many pertinent information requests are made about monitors. Because there is no standard or common list of relevant questions consistently applied to all monitors, particular pieces of data are apt to be overlooked. The standardization of information requests concerning other safeguards components is also a consistent problem throughout the SFi Guide.

$\underline{\text { Impact }}$

Making the SFC Guide questions and formis standard would provide uniformity and systematic thoroughness, as well as assist the analyst by providing consistency and repeatability. Using the form as it is might result in difficulty in organizing data ana perhaps even in incomplete data upon which to perform an assessment. 


\section{Finding 2}

The overall organization and format of the SFC Guide is not conoucive to efficiently and directly establishing an input data base for performing an automated assessment. An example of the SFC Guide organization of the information request sheets, which are ordered and addresseo in alphabetical sequence, is in Appendix $A$ of this report. The safeguaras component information categories, upon which the LSD organization is based, is also shown in Appendix A. A correlation between the SFC Guide and LSD organizations is drawn in terms of subject matter and information content addressed by both documents. Thus, Appenaix A illusträtes two of our findings: first, the LSD and SFC Guide elicit much the same information; second, the LSD and SFC Guide organize information differently.

\section{Impact}

The organization of the SFC Guide does not facilitate generating and assimilating information in a form for automatea assessment. Information collected under the organization of the SFC Guide will have to be reorganized and reformatted to establish a suitable input base compatible witn the automated assessment. 
Significant SFC Guide/SAA LSD comparison findings are listed in succinct form below:

- Significant SFC Guide information deficiencies include:

- SNM piping system information is absent.

- Safeguards system interconnectivity information is incomplete.

- Signal transmission and utility system information is incomplete.

- Probabilistic information is incomplete.

- Facility operational mode information is incomplete.

- Licensee interpretation of to SFC requests may be sufficiently uncertain to preclude data completeness.

- A partial SAA assessment, given licensee responses to the SFC requests, is nonetheless possible. The impact of the deficiencies on performing an SAA assessment include:

- A fairly thorough Level 1 analysis is possible.

- At least partial analysis on Levels 2, 3, and 4 is possible.

- Reorganizing and reformatting the input data and information may often simplify an automated assessment.

- Significant and critical safeguards vulnerabilities may be missed due to deficiencies in SFC Guide coritent

In light of the independent parallel development of the SFC Guide and the SAA LSD, there is surprising overlap in information content addressed. Also, new NRC initiatives regarding information requests, especially as illustrated by recent revisions to the SFC Guide document, appear to be such as to more readily accommodate automated assessments. 


\section{ACKNOWLEDGMENTS}

The authors wish to acknowledge A. D. Scarpetti fur editorial assistance ana

M. M. Kirschten for preparing the manuscript. They also wish to thank

D. R. Dunn and A. J. Poggio for critical reviews. 


\section{REFERENCES}

1. A. A. Parziale, The Licensee Submittal Document Content and Format for Material Control and Accounting Assessment, Volume II, Lawrence Livermore National Laboratory, Livermore, CA. NUREG/CR 1233, UCRL 52735 (1979).

2. Fixed Site Physical Protection Upgrade Rule Guidance Compendium, Volume I, U.S. Nucilear Regulatory Commission, Drät, (1978). (Final version pubitished Jurie 1980 as NUREG-0669, Volume I;

$\mathrm{ADS} / \mathrm{mk}$ 
APPENDIX A

\begin{tabular}{|c|c|c|c|c|c|c|c|c|c|}
\hline & \multicolumn{9}{|c|}{ LSD S/G component categories } \\
\hline Subjects of SFC guide information request sheets & $\begin{array}{c}\text { Facility } \\
\text { locations }\end{array}$ & $\begin{array}{c}\text { Piping } \\
\text { system } \\
\text { element }\end{array}$ & $\begin{array}{c}\text { Material } \\
\text { transfer } \\
\text { procedures }\end{array}$ & $\begin{array}{c}\text { Control } \\
\text { monitors }\end{array}$ & $\begin{array}{c}\text { Utility } \\
\text { system } \\
\text { components }\end{array}$ & $\begin{array}{l}\text { Signal trans- } \\
\text { mission syst. } \\
\text { components }\end{array}$ & $\begin{array}{c}\text { Facility } \\
\text { personnel }\end{array}$ & $\begin{array}{l}\text { Accounting } \\
\text { system } \\
\text { components }\end{array}$ & $\begin{array}{c}\text { Facility } \\
\text { operational } \\
\text { modes }\end{array}$ \\
\hline Admittance authorization criteria \& schedules & & & 1 & 1 & & & & & 1 \\
\hline Admittance authorization/verification procedures & & & & 1 & & & & & \\
\hline Air \& utility inlet barriers & 1 & & & & & & & & \\
\hline Annunciation systems & & & & 1 & & & & & \\
\hline Area zoning & & & & 1 & & & & & \\
\hline Balanced magnetic switches & & & & 1 & & & & & \\
\hline Breakwire systems & & & & 1 & & & & & \\
\hline Buried line sensors & & & & $T$ & & & & & \\
\hline Capacitance alarms & & & & T & & & & & \\
\hline CCTV monitoring & & & & 1 & & & & & \\
\hline CCTV systems & & & & 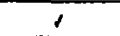 & & & & & \\
\hline Central \& secondary alarm stations & 1 & & & 1 & & & & & \\
\hline Close out inspection by 3rd party & & & & J & & & & & \\
\hline Coded credential systems & & & & 1 & & & & & \\
\hline Commercial telephone system & & & & & & 1 & & & \\
\hline Contingency plans \& procedures & & & & & & & & & 1 \\
\hline Controlled security lighting & & & & & 今. & & & & \\
\hline Data link via R.F. & & & & & & 1 & & & \\
\hline Direct line telephonejintercom & & & & & & 1 & & & \\
\hline Direct monitoring/surveillance & & & & 1 & & & & & \\
\hline Doors and associated hardware & e & & & & & & & & \\
\hline Duress alarms & & & & 2 & & & & & \\
\hline E-field fence & & & & 1 & & & & & \\
\hline Electrical sensor \& tilt switch & & & & 1 & & & & & \\
\hline Emergency access procedures & & & & & & & & & 1 \\
\hline Emergency battery system & & & & & 1 & & & & 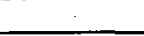 \\
\hline Emergency evacuation procedures & & & 1 & & & & & & 1 \\
\hline \multicolumn{10}{|l|}{ Emergency exits } \\
\hline Emergency generator svstems & & & & & 1 & & & & \\
\hline \multicolumn{10}{|l|}{ Equipment checks/maintenance } \\
\hline Escorts & & & & 1 & & & & & 1 \\
\hline Explosive detector-hand held, package & & & & 1 & & & & & \\
\hline Explosive detector-hand held, personnel & & & & - & & & & & \\
\hline Explosive detector-hand held, vehicle & & & & 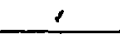 & & & & & \\
\hline Explosive detector-walk through & & & & $\therefore$ & & & & & \\
\hline Explosive detector-volume & & & & 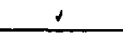 & & & & & \\
\hline Fense systems & 1 & & & & & & & & \\
\hline Floors, roofs, walls & 1 & & & & & & & & \\
\hline Functional zoning & 1 & & & & & & & & \\
\hline Gates \& associated hardware & 9 & & & & & & & & \\
\hline Guard force personal equipment & & & & & 1 & & & & \\
\hline \multicolumn{10}{|l|}{ Guard force qualifications } \\
\hline \multicolumn{10}{|l|}{ Guard patrols/interventian } \\
\hline Guard post assignments & & & & 1 & & & & & \\
\hline
\end{tabular}


APPENDIX A (Continued)

\begin{tabular}{|c|c|c|c|c|c|c|c|c|c|}
\hline & \multicolumn{9}{|c|}{ LSD S/G component categories } \\
\hline Subjects of SFC guide information request sheets & $\begin{array}{c}\text { Facility } \\
\text { locations }\end{array}$ & $\begin{array}{c}\text { Piping } \\
\text { system } \\
\text { element }\end{array}$ & $\begin{array}{c}\text { Material } \\
\text { transfer } \\
\text { procedures }\end{array}$ & $\begin{array}{c}\text { Control } \\
\text { monitors }\end{array}$ & $\begin{array}{c}\begin{array}{c}\text { Utility } \\
\text { system } \\
\text { components }\end{array} \\
\end{array}$ & $\begin{array}{l}\text { Signal trans- } \\
\text { mission syst. } \\
\text { components }\end{array}$ & $\begin{array}{c}\text { Facility } \\
\text { personnel }\end{array}$ & $\begin{array}{l}\text { Accounting } \\
\text { system } \\
\text { components }\end{array}$ & $\begin{array}{c}\text { Facility } \\
\text { operational } \\
\text { modes } \\
\end{array}$ \\
\hline Hardwire video system & & & & 1 & & & & & \\
\hline Infrared beam system, exterior & & & & 1 & & & & & \\
\hline Interfaces between alarm stations \& sensors & & & & & & 1 & & & \\
\hline Isolation zones & 1 & & & & & & & & \\
\hline K.9, use of, package search & & & & 1 & & & & & \\
\hline vehicle search & & & & 1 & & & & & \\
\hline Local audible/visible alarms & & & & 1 & & & & & \\
\hline Locks & $\mathrm{g}$ & & & & & & & & \\
\hline Manual alarm recording & & & 1 & & & & & & \\
\hline \multicolumn{10}{|l|}{ Manual alarm recording } \\
\hline Microwave system, exterior & & & & I & & & & & \\
\hline Mobile radio & & & & & & 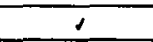 & & & \\
\hline Motion detectors & & & & 1 & & & & & \\
\hline Multiman rule & & & & 1 & & & & & \\
\hline Pat down search & & & & 1 & & & & & \\
\hline Night vision search devices & & & & , & , & & & & \\
\hline Personal identification numbers & & & $\mathrm{I}$ & & & & & & \\
\hline Photo ID badges & & & 1 & & & & & & \\
\hline Physical controls \& procedures for keys & & & 1 & & & & & & \\
\hline Portable radio & & & & & & 1 & & & \\
\hline Positive personnel ID & & & & 1 & & & & & \\
\hline \multicolumn{10}{|l|}{ Response vehicles } \\
\hline \multicolumn{10}{|l|}{ Saltyport pedestrian } \\
\hline \multicolumn{10}{|l|}{ Sallyport vehicle } \\
\hline Shielding detectors-volume & & & & 1 & & & & & \\
\hline Shielding detector-walk through & & & & 1 & & & & & \\
\hline SNM detector-hand held, package search & & & & 1 & & & & & \\
\hline SNM detector-hand held, personnel search & & & & I & & & & & \\
\hline SNM detector-volume & & & & 1 & & & & & \\
\hline SNM detector-walk through & & & & 1 & & & & & \\
\hline SNM holding/storage areas & & 1 & & & & & & & \\
\hline SNM identification/authorization procedures & & & , & & & & & & \\
\hline SNM liquid \& solid waste handling procedures & & & 1 & & & & & & \\
\hline SNM scrap removal procedures & & & 1 & & & & & & \\
\hline SNM shipping and receiving procedures & & & $\mathrm{T}$ & & & & & & \\
\hline Tamper indicating \& tamper seal protection & & & 1 & 1 & & & & & \\
\hline \multicolumn{10}{|l|}{ Tamper indicating circuitry } \\
\hline Team zoning & & & & 1 & & & & & \\
\hline Uninterruptible power systems & & & & & 1 & & & & \\
\hline Vaults & 1 & & & & & & & & \\
\hline Vibration sensors & & & & , & & & & & \\
\hline Visual inspection & & & & I & & & & & \\
\hline Weapons detector-hand held, personnel search & & & & 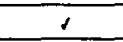 & & & & & \\
\hline Weapons detector-volume & & & & 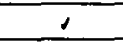 & & & & & \\
\hline Weapons detector $\cdot$ walk through & & & & 1 & & & & & \\
\hline
\end{tabular}


APPENDIX A (Continued)

\begin{tabular}{|c|c|c|c|c|c|c|c|c|c|}
\hline & \multicolumn{9}{|c|}{ LSD S/G component categories } \\
\hline Subjects of SFC guide information request sheets & $\begin{array}{l}\text { Facility } \\
\text { locations }\end{array}$ & $\begin{array}{l}\text { Piping } \\
\text { system } \\
\text { element }\end{array}$ & $\begin{array}{l}\text { Material } \\
\text { transfer } \\
\text { procedures }\end{array}$ & $\begin{array}{l}\text { Control } \\
\text { monitors }\end{array}$ & $\begin{array}{c}\text { Utility } \\
\text { system } \\
\text { components }\end{array}$ & $\begin{array}{l}\text { Signal trans- } \\
\text { mission syst. } \\
\text { components }\end{array}$ & $\begin{array}{l}\text { Facility } \\
\text { personnel }\end{array}$ & $\begin{array}{l}\text { Accounting } \\
\text { system. } \\
\text { components }\end{array}$ & $\begin{array}{l}\text { Facility } \\
\text { operational } \\
\text { modes }\end{array}$ \\
\hline Weapons-handgun & & & & 1 & & & & & \\
\hline Windows and associated hardware & 1 & & & & & & & & \\
\hline X-ray package/container search & & & & 1 & & & & & \\
\hline
\end{tabular}




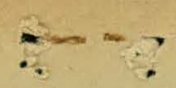

Technical Information Department - Lawrence Livermore Laboratory

University of California - Livermore, California 94550

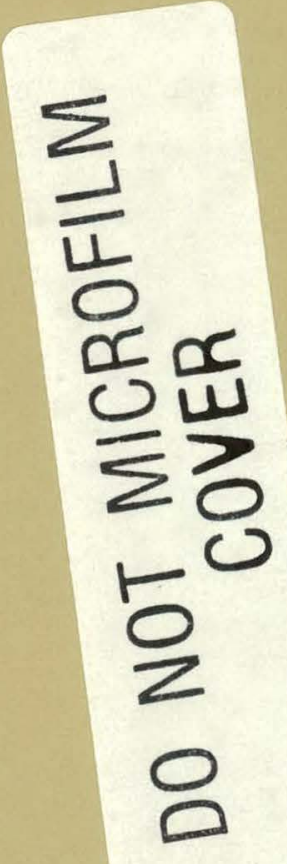

